\title{
Building a Research Library
}

Should the acquisition policy of the research library be inclusive or selective? The librarian of the Newberry Library presents the case for selectivity.

$\mathrm{A}^{\mathrm{T}}$ ANY TIME within the last two hundred years comment on this assigned topic would have taken both courage and humility. Comment today, in the middle of an intellectual revolution which is affecting our concepts of research, takes a measure of foolhardiness to boot. The only justification for any librarian putting himself into such a vulnerable position is that, simply because he is a librarian, he must come to some conclusions of his own. The real burden, the real responsibility, of building a research library falls on his shoulders. He is expected to put on its shelves both books which scholars want now and books which they will want fifty or a hundred years hence. He must hazard some guesses therefore about the meaning of research and distinguish to his own satisfaction between the various mental exercises to which that honorable name today is applied, knowing well that what he himself does will have some influence upon the character of research in the future. If the president of his university or the dean of his graduate school is a farsighted man, he may get some help there. But mostly he must act alone.

What therefore shall the librarian buy or beg? To what, out of this Niagara of modern print and typescript, shall he pay the dignity of preservation? What shall he try to acquire in the out-of-print market or rescue from attics and their equivalent?

To these questions, which represent the most important of the librarian's many functions, he seems to be giving four main answers.

\section{Leave-It-to-the-Faculty Method}

The easiest and perhaps the wisest answer involves the simple recognition of the fact that the great libraries of the world have been accumulated by many hands and minds. The accumulation has been often accidental. In this niche are books on sixteenth century Italian mechanics, sought out patiently over many years by a great subway engineer; in that, is the rare and precious library of a man who liked Bibles and Shakespeare, Bunyan and the Roman Index. Here sit the working books of a scholar who made the Risorgimento his field; there, a thousand volumes on the Frisian language put together by a dictionary-maker with a special hobby. Every library of standing has treasures so amassed, and they give it its variety and its glory. They represent the interest and quirks of those rare and gifted individuals who simply like to collect books, and perhaps the best thing for a librarian to do is first to encourage his administration to hunt out and appoint to endowed chairs more professors who are such individuals and then to turn over to them enough money each year to satisfy their desires. Three university libraries in 
this country, in turn, have been wise enough to give his own way to one great English historian who was just such a collector; each of them has been permanently enriched thereby.

Unfortunately this method, if method it can be called, does not work out as well as it might. Librarians would have an easy time of it if there were attached to their staffs, as in theory is the case in a university, a group of scholars telling them what to buy. Most professors, however, lack the collecting instinct. They expect a book to be on the shelves when they want it. Some will make recommendations now and then or even put in a list of desired books. But few have the urge to read catalogs or keep a weather eye out for libraries which might be acquired or chase down in person some alluring lead.

In a few places librarians still unhappily appear to resent "interference" from the faculty, as if a suggestion that they buy a book impugned their judgment and criticized their fitness for their job.

Nor do university administrations, in appointing new professors, always pay sufficient attention to the strengths of the library. Every library has in it more than one magnificent torso, a splendid collection of books on some subject which was lovingly acquired during some great scholar's life and never either kept up or even used after his death. There it lies, accumulating dust, to the sorrow of other scholars in the field and to the dismay of its custodian. The new man who could develop it, attract students, and turn out useful work, may sit elsewhere without the tools he needs, while the administration chooses someone in a different field.

The leave-it-to-the-faculty method of building a research library, then, while potentially the best and soundest, is too clogged by lack of cooperation between administration, faculties, and librarians to be wholly depended upon. The librarian must develop others.

\section{Follow-the-Crowd Method}

He may be forgiven, if not praised, for adopting the follow-the-crowd method. There are fads in book collecting. Fifty years ago a Doré-illustrated book cost money and a Zenger imprint could be picked up for a dollar. Today it is the Zenger which is sought for. Fashions derive from various sources. A famous doctor may get an interest in old medical books, encourage the development of medical history, send prices sky-high, and cause every medical library in the country to follow suit. Not long ago a Petty or a Bentham nestled among the other tenshilling books in a catalog; now they are headlined. The cause is the development of interest in the history of economic theory, itself an expression, in these days of conflicting ideologies, of a general interest in the history of thought. Printed lists of the hundred best books or of high spots, if launched with some authority behind them, may likewise become guides to buying. They reflect, in a way, our recent discovery of the richness of our American heritage. Infected by the same discovery are those libraries which have recently gone in for Western Americana, though yesterday no one in them knew the difference between a Hall and a McKenney and Hall. A librarian who keeps up with the procession by following current trends in collecting can console himself with the thought that at any rate he can never be behind it. Such buying, of course, is expensive. It is also an illustration that in the book business the economic laws of perfect competition, with all the 
wastefulness which it brings, still apply. It also seems a little unoriginal and uncertain.

\section{Grab-All Method}

In order to escape such uncertainty some librarians follow the grab-all method. That method requires careful examination. It is based upon a kind of faith, a philosophy of scholarship, that every piece of paper with marks upon it has now or will some day have value to some as yet unidentified researcher. People who hold this faith in an extreme form shudder whenever they hear of anything being destroyed through carelessness or intent. They lay undiscriminating hands upon all they can get and to the best of their ability see to it that nothing which may some day throw light upon this civilization or its predecessors shall perish from the earth. It is a laudable ambition, not the less laudable for being completely unrealizable.

For of course it is physically impossible to realize. There is not enough warehouse space available to libraries at the moment to save even a single year's output of books, pamphlets, advertising material, magazines, reports, and especially letters. Nor can everything which might some day be of value to an unknown student possibly be got and stored away. Some editors of learned journals deliberately and in malice clean out their correspondence files every six months, thereby making it impossible for any student to appraise finally their judgment, editorial skill, and acumen. Writers destroy their first drafts. How many university librarians make systematic effort to acquire all the letters and papers of each of their faculty -these records of valiant fighters against the forces of ignorance and indifference? Who does or should do anything about the wastebaskets of the world, with their daily evidence of the hopes and burdens of mankind? Clearly enough, they are emptied and will continue to be emptied. All librarians, even the grab-all variety, are therefore selective librarians. Selectivity is forced upon them; whether they will or no, strive as ever they may not to be, they are selective still. Some things indeed they may save, but the precious things, the working notes of some twentieth century Shakespeare, say, are bound to join those of his predecessor in oblivion.

Philosophically speaking, the grab-all method represents a curious and transitory characteristic of much modern scholarship. In Europe they speak of "la méthode statistique, la méthode Américaine." Those who apply it have the conviction that truth is mathematical, that it can be found by counting. If a hundred Babylonian tiles give us some insight into the nature of ancient business and social transactions, a hundred thousand would give a thousand times as much. In its worst form, this kind of scholarship has produced such dissertations as that famous one on the use of the word "the" in the sixteenth century; it has permitted hundreds of graduate students to believe that the worth of their papers is directly proportional to the length of their bibliographies; and it has turned out as doctoral dissertations some of the most ephemeral and worthless literature of our time. It is this kind of thinking which has set us to saving all the records of this present war and even devising new methods of making them to save, in such quantities that they can never all be used or understood. From the voluminous records of the last war few books have been written, and the Public Records Office is full of material on wars a century old which has never 
been combed. There is such a thing, as every scholar knows, as having too much material, material in amounts which swamp judgment, stultify the imagination, and kill productive scholarship, which must feed on ideas and not figures. Good books come from the mind and not from card files, and a man might measure and index every brush stroke of Michelangelo, without understanding at all why his painting is good.

My main point - that some selection on some basis is desirable, inescapable in fact -is nothing new. It is known to all great scholars. Some years ago the leading authority on the Old South, in company with a group of young students, looked over with a view to purchasing for a university library some fifteen large cases of letters which had been accumulated by a prewar Southern family. The youngsters would have bought the lot; the master picked out a single small assortment. "These only are worth keeping," he said; "I don't care what happens to the rest."

\section{Buy-a-Good-Book-When-You-See-It Method}

Let us call the fourth, the last, and the best method of building a research library the buy-a-good-book-when-you-seeit method. It is a definition of an aim adaptable in many ways. It holds good both for the great library and the small special one. A mass of manuscript, a pile of tracts, a litter of pamphlets, a bookseller's catalog, or a publisher's weekly-its principles, which are variable, can be applied to them all. In essence this is the method used by all librarians who recognize that not all of anything, not even of incunabula or 1640 books, is worth saving, who have the conviction and the courage to say, "I will not have that book in this library." Since in the nature of things librarians are compelled to be selective, it lets them be selective according to principles.

Not, of course, to any single set of principles. Heaven forbid that all libraries should be alike. Some rejoice in buying for quality's sake materials which others would not have in the place. Some may even buy, in a single field or two, what most others would consider trash. But the point remains, that a book is not bought because someone wrote it and persuaded or paid a publisher to put it out but because it is something for which at least one intelligent critic can find good reason. It is not sufficient reason for acquiring material in which no firstrate critic can see any merit whatsoever that some day some poor graduate student may be lured or forced in to wading through it. Posterity will give thanks to be spared that dissertation.

Specifically, then, the great research library should deliberately set out to acquire the best books in any field. That is no easy assignment. The British Museum, perhaps because it is a deposit library, does not have all the best books printed in the English language. It was ten years before a certain book written by an American scholar, a minor classic in its field, was acquired by the British Museum.

One of the skills we lack is intelligent bibliography-making. Libraries put out proudly long lists of all their holdings in some subject, with a worthless item which should have been stifled at the moment of its birth occupying as much space as the best book in the field. The student can't distinguish between them, and the list doesn't tell him. He flounders, wastes time, and comes to distrust all 
such inclusive lists, which thereby serve no purpose but the encouraging of other libraries to acquire what they should not need. An intelligent young scholar of my acquaintance, recently faced with the problem of naming and commenting upon all the best editions, all the best supplemental material, and all the best secondary work in his field, came to the conclusion, after looking at lists and socalled bibliographies, that there was a vast conspiracy on the part of libraries to compel him to spend his time on trash and inferior stuff. Library schools might well emphasize courses in selective bibliography-making; it is an art which can be acquired.

In the new Cambridge bibliography of English literature there are some $\mathbf{2 5 0 0}$ entries under Shakespeare. Perhaps forty of these are really good books which contribute something to our critical appreciation and understanding. By that same proportion, if there are fifteen million books in the world-or is it ten or twenty-250,000 of these do the job of carrying the accumulated wisdom and knowledge of civilized man. Go further if that figure seems pitifully small. Say there are two or three hundred books on Shakespeare which a thoughtful scholar ought to read before he ventures into a book of his own. By that proportion a library of a million and a half volumes, if they were the right ones, would suffice for the creative scholar. Only the bookkeeping kind of scholar, the counter, would find them too few.

\section{Conclusion}

The point of this brief paper is the same point which is being made today in other connections. The librarian who deliberately and undiscriminately gathers in everything he can is traitor to our civilization, which has always, until the last half-century or so, recognized that some things are better than others. $\mathrm{He}$ is preserver of mediocrity, slave to the fiction of size, and servant to a specious gospel of relativity in human affairs.

A final word, lest those in the preceding paragraph seem much too uncritical, should be said on special collections. If a great research library has the best books on all subjects, it should have too its special collections, which are deliberately more inclusive and which give it, to repeat, its variety and glory. If collected by a scholar or a discriminating collector, these too will be selective. It would be a poor Shakespearean library, a travesty on scholarship and the bard both, that bought every pamphlet which contained his name. The tragedy about special collections is that, among modern libraries, they are too often duplicated. It is a strange commentary upon the comradeship which binds scholars together that one librarian, if he has started a collection on, say, accipitraria, scarcely dare tell his brother librarian. There is no need for duplication of collections which only a handful of scholars, within the next century or so, will ever use. Let the accipitrarians travel to their books. On the other hand, there is great need for the starting of new special collections, either on new subjects like plastics or neo-mercantilism or jive which our changing age produces or on the many interests of every description in the local region where the library is situated. Such a service to one's own community will nourish, in time, that local patriotism upon which all sound national feeling must be based and without which international understanding is impossible. 